\title{
Erratum to: Notch1 hallmarks fibrillary depositions in sporadic Alzheimer's disease
}

E. Brai ${ }^{1}$, N. Alina Raio ${ }^{1}$ and L. Alberi ${ }^{1,2,3^{*}}$

\section{Erratum}

The authors of the original article [1] would like to make the readers aware that the acknowledgements section of this article was incomplete.

The updated text should read as follows:

We are particularly grateful to Prof. Francis (King's College London, UK) for his valuable feedback on our submission for human samples to the Brain Bank for Dementia, UK. We would like to gratefully acknowledge all donors and their families for the tissue provided for this study. Human tissue samples were supplied by the Brains for Dementia Research programme, jointly funded by Alzheimer's Research UK, the Alzheimer's Society and the Medical Research Council, and sourced from the Oxford Brain Bank. The Oxford Brain Bank is also supported by the National Institute for Health Research (NIHR) Units.

We are sorry for any inconvenience caused.

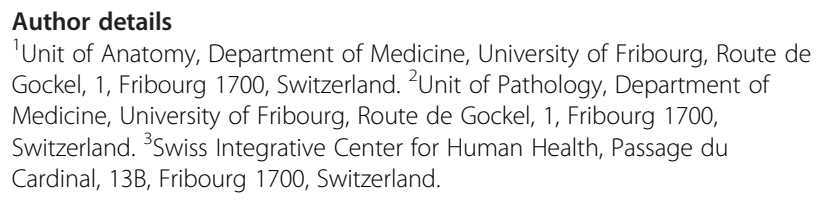

${ }^{1}$ Unit of Anatomy, Department of Medicine, University of Fribourg, Route de Gockel, 1, Fribourg 1700, Switzerland. '2Unit of Pathology, Department of Medicine, University of Fribourg, Route de Gockel, 1, Fribourg 1700, Switzerland. ${ }^{3}$ Swiss Integrative Center for Human Health, Passage du Cardinal, 13B, Fribourg 1700, Switzerland.

Received: 13 July 2016 Accepted: 1 August 2016 Published online: 25 August 2016

\section{Reference}

1. Brai E, et al. Notch1 hallmarks fibrillary depositions in sporadic Alzheimer's disease. Acta Neuropathol Commun. 2016;4(1):64.

\footnotetext{
* Correspondence: lavinia.alberi@unifr.ch

'Unit of Anatomy, Department of Medicine, University of Fribourg, Route de Gockel, 1, Fribourg 1700, Switzerland

${ }^{2}$ Unit of Pathology, Department of Medicine, University of Fribourg, Route de Gockel, 1, Fribourg 1700, Switzerland

Full list of author information is available at the end of the article

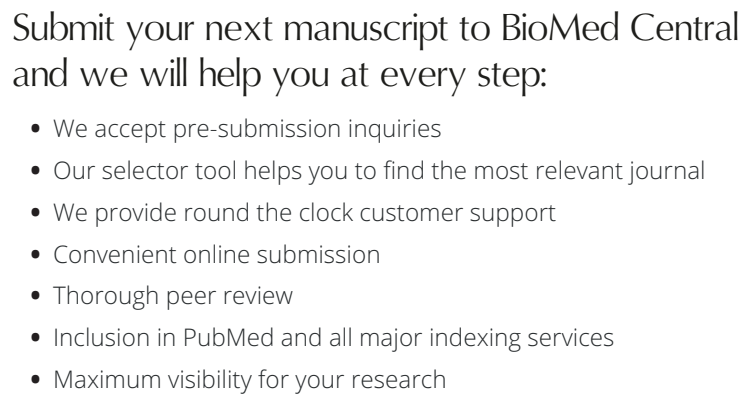

- We accept pre-submission inquiries

- Our selector tool helps you to find the most relevant journal

- We provide round the clock customer support

- Convenient online submission

- Thorough peer review

- Inclusion in PubMed and all major indexing services

- Maximum visibility for your research

Submit your manuscript at www.biomedcentral.com/submit 